\title{
KOMUNIKASI PEMASARAN BAGI PASAR LANJUT USIA (Studi Kasus Pada Promosi Jasa Tukang Gigi Hoe Sioe Shen)
}

\author{
Monika Teguh ${ }^{1 *}$, Kevin Joshua Humardani ${ }^{2}$, Seraphine Amadea Pratama ${ }^{3}$ \\ ${ }^{1,2,3}$ Program Studi Ilmu Komunikasi, Fakultas Ilmu Komunikasi dan Bisnis Media, Universitas Ciputra Surabaya \\ Email: ${ }^{1 *}$ monika.teguh@ciputra.ac.id; ${ }^{2}$ kjoshua@ $@$ student.ciputra.ac.id; ${ }^{3}$ spratama05@student.ciputra.ac.id \\ *Penulis korespondensi
}

\begin{abstract}
ABSTRAK
Penelitian ini bertujuan untuk mengetahui upaya komunikasi pemasaran yang dapat menembus pasar lansia, dimana akibat degenerasi para lansia sulit untuk melakukan komunikasi namun tentunya masih memiliki kebutuhan pribadi yang perlu dipenuhi. Salah satu kebutuhan dari lansia adalah protesa gigi untuk membantu para lansia mengkonsumsi makanan seharihari. Di kota Surabaya terdapat jasa tukang gigi Hoe Sioe Shen yang telah melayani jasa pembuatan protesa gigi selama 76 tahun. Penelitian ini dilakukan menggunakan metode studi kasus yang menjabarkan komunikasi pemasaran yang dilakukan oleh Hoe Sioe Shen. Hasil penelitian ini menyatakan bahwa komponen promotional mix primer atau yang paling efektif pada perusahaan Hoe Sioe Shen adalah word of mouth (WOM), personal selling, dan sales promotion yang didukung dengan komponen lainnya dalam menjalankan komponen primer yaitu public relations. Namun Hoe Sioe Shen tidak melakukan beberapa komponen seperti advertising, online marketing, dan direct marketing walaupun terdapat peluang untuk dilakukan.
\end{abstract}

Kata kunci: Komunikasi pemasaran, promosi, pasar lansia, tukang gigi.

\begin{abstract}
This study aims to determine the marketing communication efforts that can penetrate the elderly market, where due to degeneration they are difficult to communicate but of course they still have personal needs that must be met. One of the needs is dental prostheses to help them eat their daily meal. In Surabaya, there is a dental artisan, Hoe Sioe Shen, who has been providing dental prostheses for 76 years. This research was conducted using case study methods to describe the marketing communication activities of Hoe Sioe Shen. The results of this study indicate that the primary or most effective promotional mix component in Hoe Sioe are word of mouth (WOM), personal selling, and sales promotion which is supported by other components in carrying out the primary component, namely public relations. However, Hoe Sioe Shen did not carry out several components such as advertising, online marketing, and direct marketing although there were opportunities to do so.
\end{abstract}

Keywords: Promotional mix, elderly market, dental artisan.

\section{PENDAHULUAN}

Komunikasi pemasaran merupakan kajian komunikasi yang turut berkembang seturut dengan perkembangan industri. Komunikasi pemasaran sendiri memiliki karakterisitik yang sangat khas dalam pelaksanaannya bergantung pada target pasar yang dituju. Umumnya kajian komunikasi pemasaran yang telah banyak dibahas adalah pada target pasar usia produktif. Komunikasi pemasaran dengan target pasar pada lanjut usia masih belum banyak dibahas, padahal target pasar ini masih memiliki potensi yang besar. Maka dari itu penelitian ini akan membahas lebih jauh mengenai komunikasi pemasaran yang diterapkan pada usaha dengan target pasar lanjut usia.

Lanjut usia atau lansia adalah sebuah kondisi dimana seseorang mulai memasuki usai 60 tahun. Di Indonesia saat ini, jumlah penduduk lansia terus mengalami peningkatan. Menurut data yang dikeluarkan oleh Kementerian Koordinator Bidang Kesejahteraan Rakyat Kedeputian I Bidang Kesejahteraan Sosial, persentase lansia di Indonesia pada era tahun 1990-an adalah 6,29\%. Kemudian pada tahun 2000 adalah $7,18 \%$ dan masih terus meningkat pada tahun 2006 hingga mencapai 8,9\%. Pada tahun 2010 diperkirakan jumlah lansia sudah mencapai 23,9 juta atau 9,77\% dari populasi keseluruhan. Diproyeksikan sampai tahun 2020 terdapat 28,8 juta lansia atau sekitar $11,34 \%$ dari keseluruhan jumlah penduduk (Saputri \& Indrawati, 2011). Jumlah populasi lansia di Indonesia juga diketahui telah menduduki peringkat keempat terbesar di dunia setelah negara China, India, dan Amerika (Departemen Kesehatan, 2014).

Melihat jumlahnya yang terus meningkat, kualitas hidup lansia akhirnya menjadi sesuatu yang krusial. Kualitas hidup lansia tersebut dipengaruhi oleh beberapa faktor, yaitu kondisi fisik, kesehatan psikologis, hubungan sosial, dan aspek lingkungan. 
Faktor kondisi fisik mencakup kesehatan, dimana lansia terhindar dari penderitaan atau ketidakmampuan akibat suatu penyakit, fungsi kognitif dan fisik yang baik untuk menjalankan aktivitas, dan kemampuan lansia untuk terlibat aktif dalam kegiatan disekitarnya. Faktor kesehatan psikologis dipengaruhi oleh tingkat stres, kondisi mental, terjaganya harga diri, penghargaan pada unsur seksualitas, serta kepemilikan keyakinan, adanya status dan rasa hormat bagi lansia. Faktor hubungan sosial meliputi kesusilaan, rasa selamat, dan kententeraman yang membuat lansia mampu memiliki ikatan dengan lingkungan sosialnya. Sedangkan faktor aspek lingkungan mencakup suasana tentram, damai, dan menyenangkan pada lingkungan tempat tinggal para lansia (Rohmah $\&$ Bariyah, 2015).

Dalam rangka menjaga kualitas hidup lansia tersebut, maka muncullah demand akan produk-produk untuk menunjang kehidupan lansia. Salah satunya adalah kebutuhan akan protesa gigi atau gigi tiruan. Protesa gigi digunakan untuk menunjang hidup para lansia, dikarenakan masalah pada kondisi fisik lansia yang terjadi akibat penuaan atau degenerasi yang biasa terjadi pada fase lansia salah satunya adalah masalah pada gigi dan mulut. Diketahui bahwa karies gigi merupakan masalah yang paling umum yang sering terjadi pada lansia, hal ini dapat disebabkan oleh beberapa faktor seperti, meningkatnya kebutuhan perawatan gigi, perubahan air ludah akibat penuaan, pola makan yang kurang seimbang, pemakaian beberapa obat-obatan yang dapat menyebabkan kondisi dalam maupun permukaan mulut kering, dan juga terbukanya sebagian akar gigi yang merupakan akibat dari penurunan gusi. Adapun salah satu metode perawatan karies gigi yang terjadi pada lansia adalah dengan melakukan pencabutan gigi, yang mengakibatkan lansia mengalami kehilangan gigi pada masa tuanya, sehingga memerlukan protesa gigi sebagai pengganti. Diketahui bahwa sampai dengan tahun 2010 jumlah pengguna protesa gigi atau gigi tiruan pada lansia di Indonesia telah mencapai 14,5 persen dari jumlah penduduk lansia di Indonesia, dan jumlah pengguna protesa gigi atau gigi tiruan di provinsi Jawa Timur mencapai 4,4 persen dari jumlah penduduk di Jawa Timur (Agtini, 2010).

Di kota Surabaya terdapat sebuah perusahaan jasa yang menangani pembuatan protesa gigi atau gigi tiruan, yaitu Hoe Sioe Shen. Menurut Irawati sebagai pemilik Hoe Sioe Shen generasi ketiga, usaha ini merupakan bisnis keluarga yang diwariskan secara turun-temurun, Hoe Sioe Shen sudah berdiri sejak tahun 1943 yang didirikan oleh Bao Chen, yang merupakan nenek dari Irawati, yang kemudian diwariskan kepada anak menantunya yaitu, Tan Giok Eng pada tahun 1989-2019. Saat ini sudah mencapai generasi ketiga yang diteruskan oleh anak dari Tan Giok Eng yaitu, Fenny Irawati. Tercatat bahwa Hoe Sioe Shen Surabaya yang sudah berdiri selama 76 tahun dan sudah memiliki banyak pengetahuan tentang gigi dan protesa gigi atau gigi tiruan dan sudah memiliki banyak pengalaman dalam menghadapi berbagai masalah pasien di mana mayoritas pasiennya berada pada umur lansia. Selama ini Hoe Sioe Shen sudah melakukan promosi untuk produknya. Keberhasilan pada kegiatan promosinya mulai dapat dirasakan pada masa pimpinan generasi kedua yaitu, Tan Giok Eng, di mana produk Hoe Sioe Shen menjadi dikenal di berbagai pulau yang ada di Indonesia seperti, Kalimantan dan Bao-Bao. Lebih jauh produk buatan Hoe Sioe Shen sudah dikenal sampai ke mancanegara, yaitu Amerika. Hal ini merupakan prestasi terbesar pada sejarah pemasaran yang dilakukan oleh Hoe Sioe Shen.

Perlu dipahami bahwa dalam memasarkan produk kepada pasar lansia tentunya banyak hambatan yang terjadi. Kondisi dan pola pikir lansia menyebabkan mereka seringkali tidak mampu mengambil keputusan pembelian sendiri. Selain itu para lansia juga memiliki kecenderungan terikat dengan suatu merek. Jika lansia sudah memiliki merek favorit, maka terdapat kecenderungan bagi mereka untuk menolak merek-merek baru (Karani \& Fraccastoro, 2010). Hal ini menyebabkan usaha promosi untuk produkproduk lansia tentu saja memiliki kekhasan yang dapat dikaji lebih lanjut. Maka dari itu penelitian ini bertujuan untuk menjabarkan bauran promosi yang dilakukan oleh jasa pembuatan protesa gigi Hoe Sioe Shen, yang telah berhasil mempertahankan eksistensinya selama 76 tahun dan menjangkau pasar lansia sampai dengan ke mancanegara. Manfaat dari penelitian ini adalah memberikan kajian bagi ilmu komunikasi pemasaran, khususnya dalam ranah promosi bagi pasar lansia, mengingat belum banyaknya kajian yang membahas mengenai promosi bagi pasar lansia.

\section{KAJIAN PUSTAKA}

\subsection{Komunikasi}

Komunikasi merupakan sebuah proses yang melibatkan pengirim pesan, pesan, media, penerima pesan, dan efek-efek yang terjadi dari proses tersebut. Lebih jauh, teori komunikasi yang dikemukakan oleh Shannon dan Waever menjelaskan bahwa pesan akan 
menjadi efektif jika pengirim pesan berhasil mengantisipasi dengan baik kebutuhan dan preferensi dari penerimanya. Jadi ketika komunikator hendak melakukan encoding pesan, dia harus memastikan proses itu akan berkorespondensi dengan bagaimana komunikan melakukan decoding pesan (Danaher \& Rossiter, 2011).

Teori komunikasi Shannon dan Weaver tersebut banyak diacu oleh bidang-bidang komunikasi massa, dimana sering dihubungkan dengan alat komunikasi, dimana alat penyiar pesan harus compatible dengan alat penerima pesan. Namun dalam komunikasi pemasaran, teori ini pun dapat dijadikan landasan. Para pelaku komunikasi pemasaran perlu menyadari bahwa terdapat jenis-jenis target pasar yang berbeda yang memiliki kebiasaan yang berbeda dalam berkomunikasi. Penting bagi para komunikator untuk merancang pesan serta memilih media yang tepat sesuai dengan preferensi calon konsumen maupun konsumen. Demikian pula pada penelitian ini, perlu dipahami bahwa target pasar yang dituju adalah kaum lansia yang memiliki cara berkomunikasi yang unik. Para lansia masih memiliki pengaruh besar terhadap produk-produk yang digunakannya, meskipun mereka membutuhkan bantuan dari keluarga atau orang lain untuk mengeksekusi pembelian. Karenanya, pelaku komunikasi pemasaran harus memastikan bahwa pesan dan media yang mereka gunakan mampu untuk menjangkau komunikan lansia tersebut.

\subsection{Komunikasi Pemasaran}

Komunikasi pemasaran adalah salah satu bagian dalam komunikasi stratejik, dimana fungsi dari komunikasi pemasaran ini adalah membuat sinergi strategi pemasaran dan cara komunikasinya, sehingga perusahaan dapat memberikan satu pesan yang konsisten. Dengan digunakannya komunikasi pemasaran, maka diharapkan perusahaan dapat merasakan dampak yang maksimal dari penggabungan disiplindisiplin komunikasi dan pemasaran (Fajar, 2017).

Dalam komunikasi pemasaran, terdapat beberapa konsep pemasaran yang perlu dirancang, diimplementasikan, dan kemudian dikomunikasikan secara terintegrasi. Perencanaan dan implementasi komunikasi pemasaran yang kompleks harus melibatkan beberapa pekerjaan manajerial, seperti analisis situasi dan identifikasi peluang (Teguh, Widjaja, et al., 2020). Program komunikasi pemasaran juga harus dilaksanakan dengan memperhatikan konsistensi pesan, sehingga tujuan dari perusahaan dapat tercapai, entah itu peningkatan brand awareness, pembelian produk, atau sampai dengan loyalitas konsumen. Adapun konsep pemasaran yang harus diperhatikan adalah penentuan segmentasi, target pasar, dan posisi perusahaan atau produk yang sering disebut dengan STP, kemudian bauran pemasaran, dan bauran promosi (Teguh, Benita, et al., 2020). Bauran promosi menjadi ujung akhir dari komunikasi pemasaran, karena di sinilah suatu produk atau gagasan dikomunikasikan kepada para komunikan.

\subsection{Bauran Promosi}

Kegiatan komunikasi pemasaran dapat diwujudkan melalui bauran promosi. Promosi adalah sebuah proses dimana perusahaan atau organisasi menyampaikan informasi yang terkait dengan produk secara persuasif untuk mendorong terjadinya pembelian (Adhianti \& Herlinda, 2020). Tujuan dari dilaksanakannya promosi adalah untuk memperkenalkan produk kepada calon konsumen, mendorong terjadinya pembelian, dan mempertahankan produk dalam ingatan konsumen. Terdapat berbagai jenis kegiatan dalam promosi. Agar kegiatan promosi yang dilaksanakan berlangsung efektif, maka perusahaan harus menentukan kegiatan apa saja yang paling tepat bagi target pasarnya dan mampu mencapai tujuan pemasaran perusahaan. Di sinilah muncul bauran promosi, yaitu kombinasi dari berbagai kegiatan promosi yang dibentuk untuk mencapai tujuan dari program pemasaran perusahaan (Stefani \& Mukti, 2012).

Kegiatan-kegiatan yang dapat menjadi bagian dari bauran promosi adalah sebagai berikut:

\section{Advertising}

Advertising atau periklanan adalah segala sesuatu berbayar sebagai bentuk dari ide komunikasi non personal, barang, atau jasa dengan sponsor yang terindentifikasi. Periklanan bertujuan membentuk awareness dari sebuah produk, membangun afeksi atau rasa suka konsumen terhadap produk, dan mendorong kepercayaan konsumen untuk menggunakan produk. Keuntungan dari penggunaan iklan adalah jangkauan iklan dapat disesuaikan serta pesan dapat diatur isinya dan dapat ditayangkan berulang (Setiawan \& Wijaya, 2020).

\section{Public Relations}

Public relations adalah sebuah kegiatan organisasi yang diciptakan untuk membangun atau membina niat baik perusahaan di antara berbagai personil publik seperti, pegawai, pemerintah, pemasok dan stakeholders (Shimp \& Andrews, 2013). Dalam pelaksanaannya public relations mencakup aktivitas untuk merancang strategic 
planning, membangun relasi dengan berbagai pihak, menggunakan berbagai teknologi, dan membuat program-program kreatif, dengan tujuan akhir untuk membangun reputasi perusahaan (Teguh, Anandari, et al., 2020).

\section{Sales Promotion}

Sales promotion adalah upaya yang dilakukan perusahaan untuk merangsang konsumen agar melakukan pembelian. Program-program sales promotion memberikan insentif atau nilai lebih, sehingga dapat mendorong terjadinya pembelian langsung (Dewa, 2018). Contoh-contoh dari kegiatan sales promotion antara lain diskon, pemberian produk tambahan secara gratis, pemberian contoh produk secara gratis, dan pemberian hadiah (Teguh, Benita, et al., 2020).

4. Personal Selling

Personal selling merupakan cara promosi dengan mengandalkan salesperson. Keunggulan utama dari jenis promosi ini adalah adanya kesempatan bagi salesperson untuk berinteraksi secara langsung dengan konsumen, sehingga dapat dilakukan improvisasi pesan menyesuaikan kondisi saat berlangsungnya komunikasi person to person. Dalam kegiatan personal selling juga dimungkinkan adanya komunikasi dua arah. Dengan demikian, perusahaan dapat memperoleh feedback secara langsung dari konsumen melalui salesperson yang bertugas (Kusniadji, 2018).

5. Direct Marketing

Kegiatan direct marketing menggunakan beberapa media untuk memperoleh respon tertentu dan mendorong terjadinya pembelian di berbagai lokasi. Contoh-contoh media yang dapat digunakan untuk melaksanakan kegiatan direct marketing yaitu face to face, direct mail, catalog, telemarketing, kiosk, dan online channel (Hendria et al., 2014). Umumnya pesan yang disampaikan dalam kegiatan direct marketing merupakan pesan yang disusun dengan format atau template yang sama, namun dilakukan penyesuaian agar penerima pesan merasa bahwa pesan tersebut lebih personal.

\section{Digital Marketing}

Digital marketing merupakan kegiatan promosi produk barang atau jasa yang dilakukan melalui jejaring internet. Contoh-contoh kegiatannya antara lain pemasaran melalui website, pemasaran melalui media sosial, optimasi mesin pencari, pemasaran pada aplikasi mobile, dan sebagainya. Terdapat beberapa keunggulan utama dari kegiatan promosi ini yaitu ruang lingkup atau jangkauan yang luas, tidak terbatas oleh waktu dan lokasi geografis, serta dapat menarget langsung pelanggan potensial (Teguh \& Ciawati, 2020).

7. Word of Mouth (WOM)

Word of mouth didefinisikan sebagai komunikasi informal terhadap konsumen tentang suatu produk atau jasa yang berdampak secara kompleks dan susah untuk dikontrol. Opinion learder mempunyai peran penting dan sangat berdampak pada WOM. Opinion leader adalah seseorang dalam jaringan sosial keluarga, teman, dan kenalan yang memiliki pengaruh khusus pada sikap dan perilaku orang lain. Secara umum gengsi menjadi jantung dari WOM, dimana jika opinion leader merekomendasikan suatu produk kepada orang lain, maka ada gengsi yang dibangun terhadap produk yang direkomendasikan tersebut (Shimp \& Andrews, 2013). Fungsi utama dari WOM adalah pembagian kerja dalam proses pengambilan keputusan konsumen. Proses pengambilan keputusan menjadi lebih mudah dan lebih sederhana ketika ada rekomendasi dari orang yang terpercaya, sehingga hal tersebut menjadi akar dari daya tarik dan kekuatan WOM. Dengan bertanya kepada orang lain apa pengalaman mereka dengan suatu produk dan meminta rekomendasi mereka, konsumen dapat mengakses sejumlah besar pengalaman tanpa harus menghabiskan waktu, uang, upaya atau mengambil risiko seperti jika harus mencoba produk sendiri (Silverman, 2011).

\section{METODE PENELITIAN}

Jenis penelitian yang digunakan dalam penelitian ini merupakan penelitian kualitatif deskriptif. Penelitian kualitatif deskriptif merupakan salah satu bentuk penelitian yang dapat dilakukan dengan cara masuk dalam suatu keadaan sosial tertentu, wawancara dengan informan yang relevan dengan topik penelitian dan kriteria serta melakukan observasi. Penelitian kualitatif deskriptif biasanya digunakan untuk mendeskripsikan atau menjelaskan suatu fenomenafenomena yang terjadi baik yang terjadi secara alami maupun buatan manusia (Winarni, 2018).

Secara khusus dalam penelitian ini akan menggunakan metode studi kasus. Studi kasus merupakan sebuah metode yang memiliki fleksibilitas, dimana metode ini dapat dirancang spesifik berdasarkan suatu kasus tertentu. Penelitian dengan metode studi kasus bertujuan untuk menangkap kompleksitas dari satu atau beberapa kasus kolektif. Berbeda dengan penelitian statistik, penelitian studi kasus tidak bertujuan untuk menghasilkan luaran yang dapat digeneralisasi (Hyett et al., 2014). 
Metode pengumpulan data yang digunakan dalam penelitian ini adalah wawancara. Penelitian ini menggunakan wawancara semi terstruktur yang termasuk kategori in-depth interview. Wawancara semi terstruktur memiliki ciri khas seperti, pertanyaan terbuka, tapi juga memiliki batasan terhadap tema, waktu yang dapat diprediksi, terkontrol, namun juga fleksibel, terdapat pedoman dalam melakukan wawancara sebagai patokan alur wawancara, memiliki tujuan untuk dapat mengerti dan memahami suatu permasalahan (Herdiansyah, 2014).

Sedangkan analisis data dalam penelitian ini menggunakan beberapa langkah sebagai berikut:

1. Data Collection, proses pengumpulan data yang dilakukan dengan menggunakan metode wawancara terhadap informan yang sesuai dengan kriteria dan didukung dengan dokumentasi. Hasil pengumpulan data akan menjadi sebuah konsep.

2. Data Reduction, dilakukan dengan menggabungkan serta menyeragamkan semua data yang diperoleh dari hasil wawancara yaitu verbatim wawancara dan dokumentasi yaitu skrip analisis dokumen.

3. Display Data, merupakan proses pengolahan data yang masih setengah jadi yang dilakukan dengan menyusun alur dalam sebuah tabel sehingga dapat ditarik kesimpulan.

4. Kesimpulan, merupakan suatu penjelasan dari semua hasil subkategori tema dan coding.

Agar penelitian ini dapat terjamin kualitasnya, maka dilakukan triangulasi data sebagai upaya untuk memastikan keabsahan penelitian. Triangulasi data adalah proses dimana data yang diambil selama penelitian dikombinasikan dari sumber yang berbeda-beda, yaitu infoman yang berbeda, tempat yang berbeda, dan waktu yang berbeda (Zamili, 2015).

\section{HASIL DAN PEMBAHASAN}

Berdasarkan hasil wawancara dan analisis data yang telah dilakukan, dapat diketahui bahwa tujuan promosi dari Hoe Sioe Shen adalah agar usaha ini dapat dikenal masyarakat secara luas dan dapat terus berkembang terutama di luar domisili Hoe Sioe Shen saat ini, yaitu kota Surabaya. Selain itu dalam melaksanakan program-program promosinya, Hoe Sioe Shen juga menjaga agar kualitas maupun brand dari Hoe Sioe Shen tetap terjaga. Maka dari itu programprogram promosi yang dilakukan tetap memperhatikan hal-hal seperti konsistensi harga agar tidak muncul kesan bahwa Hoe Sioe Shen merusak harga pasar.
Bauran promosi yang dilaksanakan oleh Hoe Shioe Shen dapat dilihat pada gambar 1 berikut:
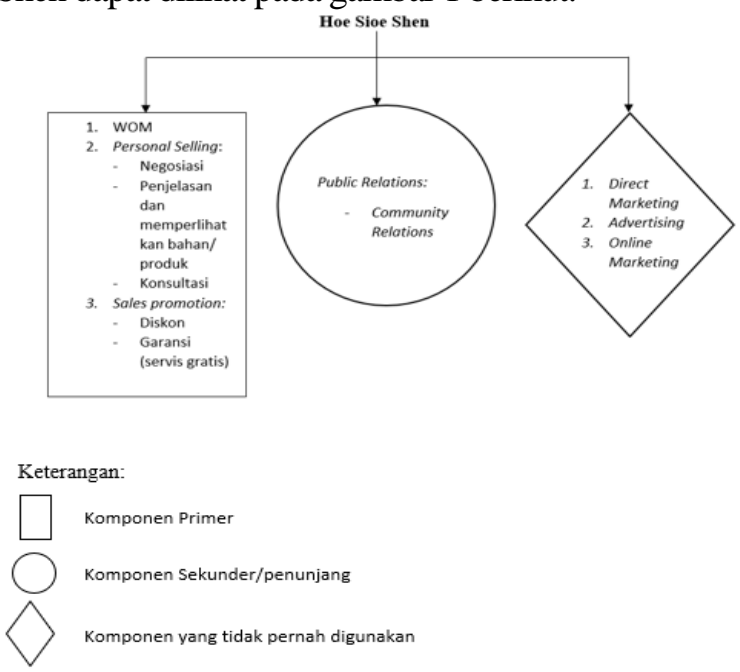

Gambar 1. Bauran Promosi Hoe Sioe Shen

Gambar di atas merupakan bauran promosi dari peusahaan Hoe Sioe Shen. Berdasarkan hasil analisis data diperlihatkan beberapa bauran promosi yang merupakan bentuk dari implementasi strategi komunikasi pemasaran mulai yang dinilai paling efektif dan sering digunakan hingga kepada bauran promosi yang tidak pernah digunakan oleh Hoe Sioe Shen. Pada bagan persegi panjang menunjukan beberapa bauran promosi yang dinilai paling efektif yang digunakan Hoe Sioe Shen mulai dari word of mouth (WOM), personal selling, dan terakhir adalah sales promotion.

\subsection{Word of Mouth}

Word of mouth dinyatakan paling efektif dalam memperoleh pelanggan di Hoe Sioe Shen. Pelanggan yang puas dengan pelayanan dan kualitas produk Hoe Sioe Shen, dengan cuma-cuma membagikan pengalamannya kepada kerabat atau temannya. Selain pelanggan yang secara aktif berbagi pengalaman, terdapat fenomena ketika orang awam melihat pelanggan yang sedang memakai protesa gigi buatan Hoe Sioe Shen. Mereka merasa penasaran terhadap protesa gigi tersebut karena terlihat bagus dan proporsional ketika dikenakan di mulut, kemudian menanyakan informasi seputar pembuatan gigi tersebut ke pelanggan Hoe Sioe Shen. Para pelanggan yang bersedia berbagi informasi positif bahkan merekomendasikan Hoe Sioe Shen, merupakan opinion leader yang dapat menstimulasi dan mendorong niat membeli seseorang.

Salah satu hal yang menarik dari WOM yang terjadi di Hoe Sioe Shen adalah adanya pelanggan-pelanggan dari luar kota, luar pulau dan luar negeri yang 
mengenal Hoe Sioe Shen melalui kegiatan ini. Kebanyakan kerabat, keluarga, atau teman dari pelanggan Hoe Sioe Shen menjadi pelanggan baru dari Hoe Sioe Shen karena mendapatkan rekomendasi. Sesuai dengan karakteristik lansia yang sulit untuk mempercayai suatu brand, maka rekomendasi dari orang-orang terdekat dan terpercaya menjadi salah satu dorongan bagi mereka untuk mencoba produk baru. Menyadari hal ini, maka Hoe Sioe Shen mendorong terjadinya WOM melalui layanan prima dan kualitas produk. Selain itu secara personal, pemilik Hoe Sioe Shen sering meminta pelanggannya untuk dapat merekomendasikan produknya.

Sayangnya usaha untuk mendorong WOM ini belum dirancang secara strategis lebih jauh. Padahal ada berbagai cara yang bisa dilakukan perusahaan untuk mendorong terjadinya WOM. Usaha untuk mendorong terjadinya WOM yang dapat dipertimbangkan oleh Hoe Sioe Shen adalah experiential WOM, yaitu upaya untuk mendorong pembicaraan mengenai brand berdasarkan pengalaman yang di-setting. Contoh kegiatannya adalah membayar seseorang atau mengundang sukarelawan untuk mencoba suatu produk kemudian membicarakannya dalam lingkungan sosialnya. Di sini orang yang dipilih untuk mencoba produk sebaiknya memiliki lingkaran sosial yang akrab dan mampu memberi pengaruh yang kuat kepada orang-orang di lingkaran itu. Selain itu para pencoba produk dapat dibekali dengan pesan yang mengandung faktor-faktor kunci yang mendorong orang untuk melakukan pembelian (Bughin et al., 2010).

\subsection{Personal Selling}

Bauran promosi selanjutnya yang juga berdampak signifikan bagi Hoe Sioe Shen adalah personal selling. Berdasarkan hasil analisis data, cara Hoe Sioe Shen menerapkan personal selling adalah dengan menjadikan pemilik dan asisten sebagai salesperson. Mereka bertugas menawarkan jasa pembuatan dan memperlihatkan bahan protesa gigi kepada pelanggan atau calon pelanggan. Dalam melakukan personal selling, para salesperson di Hoe Sioe Shen menerapkan sikap jujur, terbuka, dan bertanggung jawab terhadap setiap hal yang ditawarkan sebagai perwujudan commitment for excellence. Hal ini juga didukung dengan pedoman yang diberlakukan dan ditekankan oleh Hoe Sioe Shen kepada sumber daya manusianya yaitu sabar, teliti, telaten dan jujur ketika melayani pelanggan. Setelah pelanggan tertarik dengan produkproduk yang ditawarkan, salesperson akan memberi- tahukan harganya dan membuka kesempatan negosiasi harga yang memungkinkan pelanggan bisa mendapatkan diskon. Proses selanjutnya jika calon pelanggan tertarik adalah konsultasi mengenai kondisi giginya dan salesperson memberikan saran-saran kepada pelanggan.

Hal yang menarik dalam menjalankan personal selling di Hoe Sioe Shen adalah karakteristik mayoritas pelanggan yang dilayani yaitu lansia. Mengingat lansia umumnya mengalami masalah dalam mengingat dan memahami sesuatu, maka mereka membutuhkan bantuan dari orang lain untuk mengambil keputusan pembelian. Maka dari itu, selain mendekati pengguna produk yaitu lansia, salesperson juga harus melakukan pendekatan kepada orang kepercayaan dari mereka, umumnya adalah keluarga. Tantangan dalam mendekati pasar lansia, sedikit berbeda dengan pasar bayi atau anak-anak yang juga membutuhkan bantuan orang terdekat untuk mengambil keputusan pembelian. Pada pasar bayi dan anak-anak, orang tua umumnya memiliki otoritas yang lebih besar dalam menentukan produk yang akan dibeli, dimana orang tua yang menjadi inisiator, decider dan buyer, sedangkan anak hanya menjadi influencer (Helmi \& Sande, 2020). Namun lansia sedikit berbeda, terkadang mereka masih dapat menuntut dan memberikan opini pribadi karena mereka merasa sebagai orang yang lebih tua dan lebih memahami kebutuhan mereka. Maka dari itu salesperson dalam melakukan pendekatan tidak bisa lebih menekankan pada keluarga, namun harus secara seimbang memperhatikan juga keinginan dari para lansia. Jika terjadi ketidaksepahaman atau perbedaan pendapat antara lansia dan keluarganya, salesperson harus secara fleksibel mampu menjembatani kedua belah pihak.

Sebagai contoh jika lansia ingin mengambil produk dengan bahan yang paling mahal sedangkan pihak keluarga tidak setuju karena harganya dirasa terlalu mahal, maka salesperson harus memfasilitasi kedua belah pihak secara seimbang. Kepada pihak keluarga salesperson bisa menjelaskan keunggulan produk yang lebih tahan lama dan lebih nyaman, sehingga dalam jangka panjang bahan ini akan lebih menguntungkan. Demikian juga kepada pelanggan lansia, dapat dijelaskan juga keunggulan bahan-bahan lain sehingga lansia tidak merasa bahwa produk yang lain buruk. Salesperson harus terlibat secara aktif dan fleksibel dalam negosiasi ini, sehingga kedua belah pihak dapat menyetujui dan puas dengan produk yang akhirnya dipilih. Interaksi yang aktif dan fleksibel antara salesperson dan pelanggan ini yang mendorong terjadinya pembelian produk. 


\subsection{Sales Promotion}

Bauran promosi ketiga yang dirasa efektif oleh Hoe Sioe Shen dalam menembus pasar lansia adalah sales promotion. Bentuk dari sales promotion yang diterapkan oleh Hoe Sioe Shen adalah diskon. Diskon dapat diberikan dalam proses negosiasi awal bersama salesperson, maupun diskon yang diberikan kepada pelanggan yang melakukan pembelian berulang beberapa kali. Pada hasil analisis data terbukti bahwa pelanggan juga merasa sangat tertarik jika diberikan diskon. Tidak hanya diskon, Hoe Sioe Shen juga memberikan penawaran after sales yaitu dengan memberikan garansi pada produk buatan Hoe Sioe Shen. Garansi berupa perbaikan protesa gigi secara gratis yang dapat diklaim oleh pelanggan Hoe Sioe Shen jika merasa ada ketidaknyamanan ketika mengenakan protesa gigi buatan Hoe Sioe Shen. Sebagai tambahan, pegawai Hoe Sioe Shen juga siap untuk datang ke rumah pelanggan yang masih dalam jangkauan secara gratis.

\subsection{Community Relations}

Aspek dari bauran promosi lainnya yang dinilai berperan sebagai pendukung proses kegiatan pemasaran adalah public relations. Dalam hal ini Hoe Sioe Shen melakukan hal yang dikenal dengan community relations. Community relations merupakan upaya perusahaan untuk menjadi bagian yang integral dalam kehidupan masyarakat yang tinggal di sekitarnya (Lattimore et al., 2010). Bentuk community relations yang dilakukan oleh Hoe Sioe Shen adalah dengan memberikan produk dengan harga khusus bagi mereka yang kurang mampu di wilayah sekitarnya, bahkan Hoe Sioe Shen juga pernah memberi gigi gratis kepada masyarakat sekitar seperti tukang becak. Hal ini juga merupakan perwujudan dari give to society yang juga memiliki dampak kepada perusahaan yaitu good corporate citizen. Dengan menjaga hubungan yang baik dengan masyarakat sekitar, Hoe Sioe Shen telah membentuk image positif. Hal ini pada akhirnya mendorong terjadinya word of mouth, yang mendorong bertambahnya jumlah pelanggan dan meningkatnya penjualan Hoe Sioe Shen.

\subsection{Ruang Pengembangan Promosi}

Aspek-aspek dalam bauran promosi yang tidak pernah dilakukan oleh Hoe Sioe Shen adalah direct marketing, advertising, dan online marketing. Berdasarkan hasil analisis data Hoe Sioe Shen tidak melakukan direct marketing dikarenakan hal tersebut dinilai dapat mengganggu orang. Terlebih beberapa pelanggan Hoe Sioe Shen sendiri juga menyatakan bahwa mereka juga tidak suka jika dihubungi oleh telemarketer. Namun hal ini sesungguhnya dapat dipertimbangkan ulang. Direct marketing masih memiliki peluang untuk dapat dilakukan di sebuah perusahaan jasa tukang gigi, asalkan perusahaan dapat memilih penawaran yang tepat untuk disebarkan kepada para pelanggannya. Sedangkan untuk advertising dan online marketing juga tidak diterapkan oleh Hoe Sioe Shen dikarenakan masih belum ada sumber daya manusia yang mumpuni untuk melaksanakan kegiatan ini. Maka dari itu, sebenarnya tidak menutup kemungkinan jika perusahaan jasa tukang gigi yang dalam kasus ini adalah Hoe Sioe Shen dapat menerapkan advertising dan online marketing. Apalagi para pelanggan dan keluarganya mulai aktif menggunakan sosial media seperti Facebook dan Instagram. Jenis promosi ini dapat menjadi peluang bagi Hoe Sioe Shen untuk berkembang lagi jika dapat mengelola kegiatan advertising dan online marketing dengan tepat.

\section{KESIMPULAN}

Berdasarkan hasil penelitian yang dilakukan dengan metode in depth interview, maka dapat disimpulkan bahwa promotional mix atau bauran pemasaran Hoe Sioe Shen yang paling efektif dalam memperoleh awareness dan juga berdampak positif pada penjualan adalah word of mouth, personal selling, dan sales promotion. Word of mouth menjadi andalan utama dimana melalui cara ini, Hoe Sioe Shen mendapatkan pelanggan sampai ke mancanegara. Namun sayangnya word of mouth ini belum dikelola lebih lanjut agar dapat lebih berdampak. Hoe Sioe Shen juga menggunakan kegiatan promosi pendukung yaitu public relations, khusunya dalam bentuk community relations, yang berdampak pada brand association dari perusahaan Hoe Sioe Shen sehingga makin dipercaya dan semakin dikenal masyarakat.

Selain itu Hoe Sioe Shen tidak melakukan beberapa kegiatan pemasaran dikarenakan tidak adanya sumber daya manusia yang memiliki kemampuan untuk melakukannya, antara lain advertising, direct marketing, dan online marketing. Namun dari hasil penelitian Hoe Sioe Shen masih memiliki peluang yang cukup banyak jika mau terjun ke beberapa kegiatan promosi yang belum terlaksana tersebut. Jika ditinjau dari perkembangan zaman yang memasuki era digital dan perubahan perilaku konsumen dalam mengakses informasi, maka dapat disarankan bagi Hoe Sioe Shen untuk mulai mengembangkan bauran promosinya menyesuaikan dengan kondisi terkini. 


\section{DAFTAR PUSTAKA}

Adhianti, A. A., \& Herlinda, H. (2020). Strategi Komunikasi Pemasaran 7P Pengelola Museum Sejarah Jakarta Dalam Upaya Meningkatkan Daya Tarik Wisatawan Mancanegara. Scriptura, 10(1), 34-42. https://doi.org/10.9744/scriptura. 10.1.34-42

Agtini, M. D. (2010). Persentase Pengguna Protesa Di Indonesia. Media Penelitian Dan Pengembangan Kesehatan, 20(2), 50-58. http://repository. litbang.kemkes.go.id/1409/

Bughin, J., Doogan, J., \& Vetvik, O. J. (2010). A new way to measure word-of-mouth marketing. In McKinsey Quarterly (Vol. 2).

Danaher, P. J., \& Rossiter, J. R. (2011). Comparing Perceptions of Marketing Communication Channels. European Journal of Marketing, 45(1), 6-42. https://doi.org/10.1108/030905611 11095586

Departemen Kesehatan. (2014). Profil keseharan Indonesia Tahun 2013. Kementrian Kesehatan Republik Indonesia.

Dewa, C. B. (2018). Pengaruh Kualitas Pelayanan dan Promosi Penjualan Jasa Grabcar Terhadap Kepuasan Pelanggan (Studi Kasus Pada Wisatawan di Yogyakarta). In Jurnal Perspektif (Vol. 16, Issue 1). www.naikuber.com,

Fajar, A. (2017). Implementasi Integrated Marketing Communication pada Tokopedia dalam Mempertahankan Pelanggan. Jurnal Komunikasi, 8(3), 210-214.

Helmi, A., \& Sande. (2020). Analisis Peran Dalam Pengambilan Keputusan Pembelian Keluarga. Jurnal Ekonomi Dan Bisnis Terapan, 14(1). https://doi.org/10.1017/CBO9781107415324.004.

Hendria, R., Ahman, E., \& Novalita, D. P. (2014). Pengaruh Program Direct Marketing Terhadap Keputusan Menggunakan Meeting Package Grand Hotel Lembang (Survei pada Tamu Bisnis di Grand Hotel Lembang). In THE Journal: Tourism and Hospitality Essentials Journal (Vol. 4, Issue 1). https://doi.org/10. 17509/THEJ.V4I1.1979.G1362

Herdiansyah, H. (2014). Metodologi Penelitian Kualitatif untuk Ilmu-ilmu Sosial. Salemba Humanika.

Hyett, N., Kenny, A., \& Dickson-Swift, V. (2014). Methodology or Method a Critical Review of Qualitative Case Study Reports. International Journal of Qualitative Studies on Health and Well-Being, 9(1), 1-12. https://doi.org/10.3402/ qhw.v9.23606

Karani, K. G., \& Fraccastoro, K. A. (2010). Resistance To Brand Switching: The Elderly Consumer. Journal of Business \& Economics Rese-
$\operatorname{arch}(J B E R), 8(12), 77$. https://doi.org/10.19030/ jber.v8i12.784

Kusniadji, S. (2018). Kontribusi Penggunaan Personal Selling Dalam Kegiatan Komunikasi Pemasaran Pada Era Pemasaran Masa Kini. Jurnal Komunikasi, 9(2), 176-183. https://doi.org/ 10.24912/jk.v9i2.1078

Lattimore, D., Baskin, O., Heiman, S. T., \& Toth, E. L. (2010). Public Relations-Profesi dan Prkatik. Penerbit Salemba Humanika.

Rohmah, A. I. N., \& Bariyah, K. (2015). Kualitas Hidup Lanjut Usia. Jurnal Keperawatan, 3(2), 120-132.

Saputri, M. A. W., \& Indrawati, E. S. (2011). Hubungan Antara Dukungan Sosial Dengan Depresi Pada Lanjut Usia Yang Tinggal Di Panti Wreda Wening Wardoyo Jawa Tengah. Jurnal Psikologi, 9(1), 65-72. https://doi.org/ 10.14710/jpu.9.1

Setiawan, W. C., \& Wijaya, L. S. (2020). Strategi Imc Dalam Mempromosikan Program Internasional (Studi kasus di Universitas Kristen Satya Wacana-Salatiga). Scriptura, 10(1), 1-14. https://doi. org/10.9744/scriptura.10.1.1-14

Shimp, T. A., \& Andrews, J. C. (2013). Advertising, Promotion, and Other Aspects of Integrated Marketing Communication. Cengage Learning.

Silverman, G. (2011). The Secrets of Word of Mouth. AMACOM.

Stefani, L., \& Mukti, A. B. (2012). Operasional konsep bauran promosi di Hotel Amaris Pemuda Semarang. Jurnal Ilmiah Dinamika Kepariwisataan, 11(2), 24-32.

Teguh, M., Anandari, P., \& Bungin, B. (2020). Aktivitas Public Relations Di Mall Ciputra World Surabaya. Communicology: Jurnal Ilmu Komunikasi, 8(1), 1-17. http://journal.unj.ac.id/

Teguh, M., Benita, A., \& Dewi, N. K. A. S. U. (2020). Pemanfaatan Komunikasi Pemasaran Terpadu Pada UMKM Snack Indochip. Journalism, Public Relation and Media Communication Studies Journal (JPRMEDCOM), 2(1), 4055. https://doi.org/10.35706/JPRMEDCOM. V2I1.3748

Teguh, M., \& Ciawati, S. T. (2020). Perancangan Strategi Digital Marketing Communication Bagi Industri Perhotelan Dalam Menjawab Tantangan Era Posmodern. Bricolage: Jurnal Magister Ilmu Komunikasi, 6(01), 51-64. https://doi.org/ 10.30813/bricolage.v6i01.2067

Teguh, M., Widjaja, E. D. N., Hartanto, L. C., \& Lukito, J. K. (2020). Implementation of Integrated Marketing Communication at Kampoeng Semarang. Proceedings of the 2nd Jogjakarta Communication Conference (JCC 2020), 459, 222-226. 
Winarni, E. W. (2018). Teori dan Praktik Penelitian Kuantitatif Kualitatif penelitian Tindakan Kelas (PTK) Reaserch and Development (R\&D). Bumi Aksara.
Zamili, M. (2015). Menghindar dari Bias: Praktik Triangulasi dan Kesahihan Riset Kualitatif. LISAN AL-HAL: Jurnal Pengembangan Pemikiran Dan Kebudayaan, 9(2), 283-304. https://doi.org/10.35316/10.1234/vol3iss2pp230 